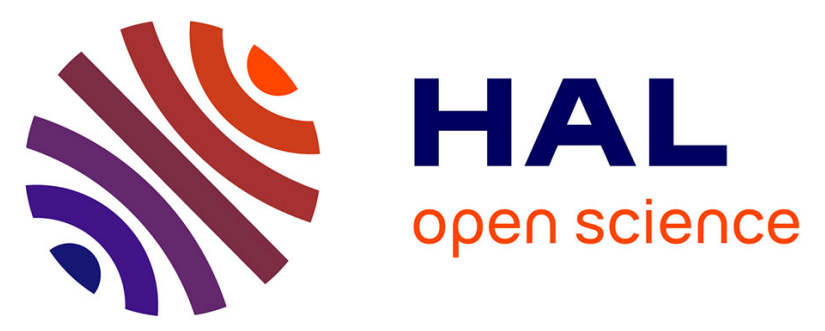

\title{
Comparative analysis of symbiont ratios and gene expression in natural populations of two Bathymodiolus mussel species
}

\author{
H. Guezi, Isabelle Boutet, Ann C. Andersen, F. Lallier, Arnaud Tanguy
}

\section{- To cite this version:}

H. Guezi, Isabelle Boutet, Ann C. Andersen, F. Lallier, Arnaud Tanguy. Comparative analysis of symbiont ratios and gene expression in natural populations of two Bathymodiolus mussel species. Symbiosis, 2015, 63 (1), pp.19-29. 10.1007/s13199-014-0284-0 . hal-01109381

\section{HAL Id: hal-01109381 \\ https://hal.sorbonne-universite.fr/hal-01109381}

Submitted on 26 Jan 2015

HAL is a multi-disciplinary open access archive for the deposit and dissemination of scientific research documents, whether they are published or not. The documents may come from teaching and research institutions in France or abroad, or from public or private research centers.
L'archive ouverte pluridisciplinaire HAL, est destinée au dépôt et à la diffusion de documents scientifiques de niveau recherche, publiés ou non, émanant des établissements d'enseignement et de recherche français ou étrangers, des laboratoires publics ou privés. 


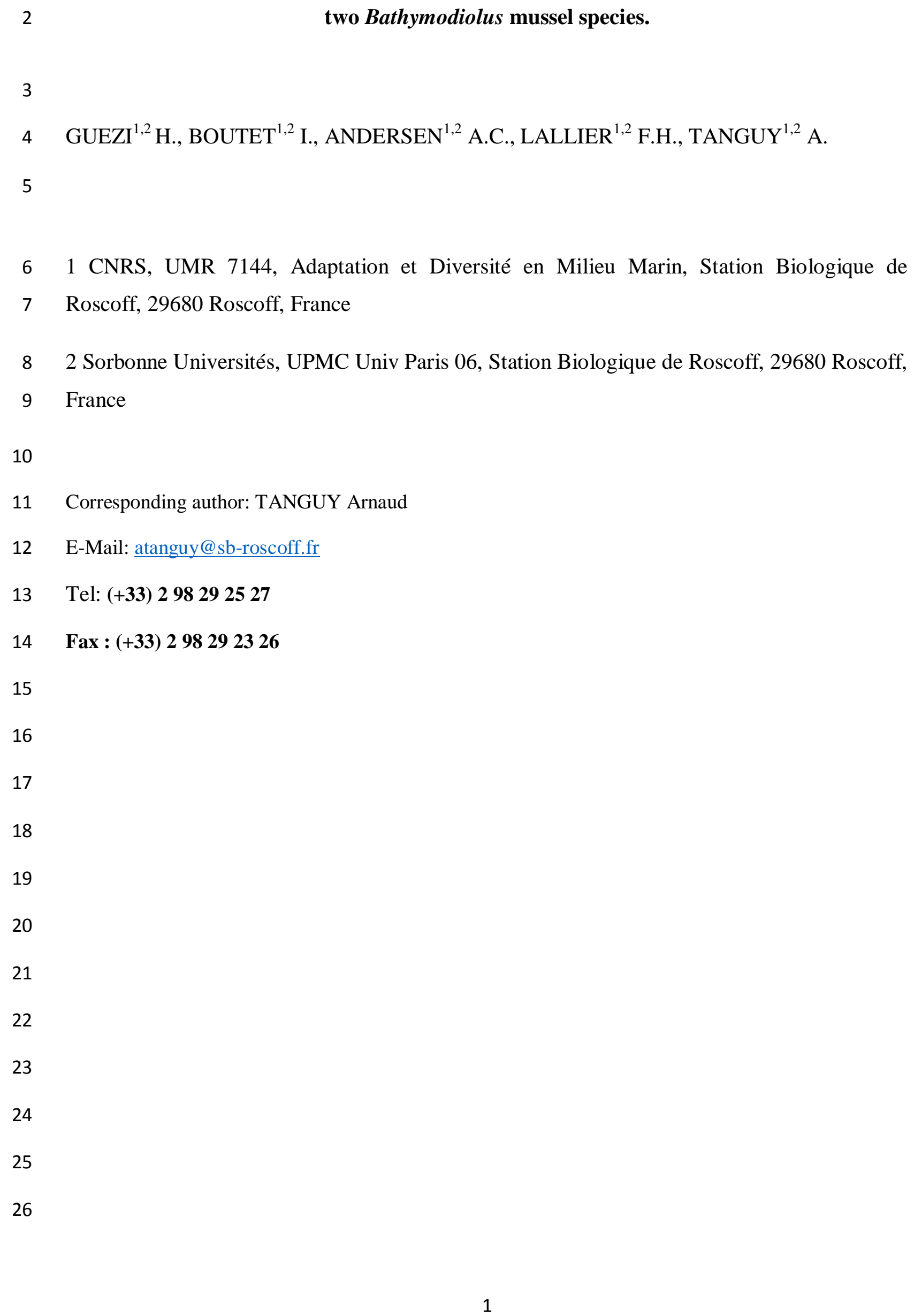




\section{Abstract}

Bathymodiolus mussels associated with deep-sea hydrothermal vents and cold seeps harbor chemosynthetic endosymbiotic bacteria in bacteriocytes located in the gill epithelium. Two distinct morphotypes of $\gamma$-proteobacteria, sulfur- and methane-oxidizing, have been identified and form a dual symbiosis in B. azoricus mussels from the Mid-Atlantic Ridge and in B. aff. boomerang from cold seeps in the Gulf of Guinea. Thiotrophic bacteria (SOX) are capable of fixing $\mathrm{CO} 2$ in the presence of sulfide or thiosulfate and methanotrophic bacteria (MOX) use methane both as a carbon and an energy source. In this study we used quantitative real-time PCR to test whether symbiont abundance and gene expression varied between the two mussel species. Results showed that B. azoricus from two hydrothermal sites had similar ratios and gene expression pattern for both symbiont types. In B. aff. boomerang, SOX ratio and ATP sulfurylase gene expression show differences between specimens collected on the different sites. Analysis of symbiont ratios in both species indicated a clear dominance of MOX symbionts in B. aff. boomerang and SOX symbionts in B. azoricus. We also evidenced that the species from the deeper sites (B. aff. boomerang) and mussels collected from sulfur and methane rich habitats showed higher symbiont ratio suggesting that environmental parameters may have significant impacts on the symbiont ratios in Bathymodiolus mussels.

Keywords: Hydrothermal vent, Cold seeps, Bathymodiolus, symbiont, FISH

Abbreviations:

DAPI: 4',6-DiAmidino-2-Phenyl-Indole, double-stranded DNA staining Cy3 and Cy5: Cyanine dyes

FISH: Fluorescencent In Situ Hybridization

MOX: Methane OXidizing bacteria

pmoA: particulate methane oxygenase, subunit A

ROV: Remotely Operated Vehicle

SOX: Sulfur OXidizing bacteria 


\section{Introduction}

Hydrothermal vents and cold seeps are two unique ecosystems that have been discovered while exploring the deep ocean. Deep-sea hydrothermal vents occur in geologically active regions of the ocean floor. Seawater percolates into the Earth's crust through fissures in the ocean floor where it is heated and modified before the water expands and rises back to the surface (Lonsdale and Becker 1985; Van Dover 2000). As it rises, the hot water dissolves minerals and other chemicals from the surrounding rocks. When it reaches the ocean floor, it mixes with cold deep-sea water, and some of the minerals precipitate out of the seawater and harden on the rim of the vent to form over the time a tall chimney-like structure (Tivey 1995; Von Damm 1995). The temperature of the water coming out of these vents may exceed $360^{\circ} \mathrm{C}$ and is characterized by a low $\mathrm{pH}$, high levels of hydrogen sulfide, methane and/or hydrogen, high metal concentrations and anoxia (Geret et al. 2002; Charlou et al. 2002; Le Bris et al. 2003; German et al. 2004).

A few years after the discovery of hydrothermal vents, another environment called cold seeps and associated with mineral-rich water rising through sedimented sea floor was discovered. Cold seeps occur in geologically active and passive continental margins where pore waters enriched in methane are forced upward through the sediments by pressure (Sibuet and Olu 1998; Kojima 2002; Levin 2005). Gradient seeps are areas where chemically derived fluids from hydrocarbon reservoirs and methane hydrates arise (Van Dover 2002; Dickens et al. 2003; Olu-Le Roy et al. 2007). Both environments share common characteristics such as the presence of reduced chemical compounds $\left(\mathrm{H}_{2} \mathrm{~S}, \mathrm{CH}_{4}\right.$ and other hydrocarbonates), local hypoxia, and abundant metabolically active bacterial populations. Hydrothermal vents and cold seeps also differ in significant ways; hydrothermal vents are characterized by locally high temperatures and strongly fluctuating reduced chemical concentrations associated with various chimney life time (Van Dover and Trask 2000; Vanreusel et al. 2010; German et al. 2004), while cold seeps are often assumed to be more stable in time, even when they show heterogeneity in their environmental characteristics (Sibuet and Olu 1998; Boetius and Seuss 2004; Vanreusel et al. 2010). Deep-sea hydrothermal vent fields and cold seeps are areas on the seafloor with great biological productivity fueled by microbial chemosynthesis and with substantial animal populations (Van Dover et al. 2003; Levin 2005; MacDonald et al. 1989; Sibuet and Olu 1998). Bathymodioline mussels are dominant constituents of the deep-sea fauna (Kenk and Wilson 1985; Nelson and Fisher 1995; DeChaine and Cavanaugh 2006; 
Dubilier et al. 2008; Génio et al. 2008). Beside vents and seeps, these mussels colonize various environments such as whale falls and sunken wood showing a great ability to adapt to different habitats (Cavanaugh et al. 2006). One key to the survival of these mussels in such environments is their association with chemosynthetic bacterial symbionts (Sibuet and Olu 1998; Van Dover and Trask 2000). All Bathymodiolus species harbor one or several types of symbionts. Some species host only sulfur-oxidizing bacterial symbionts (Nelson et al. 1995; Fujiwara et al. 2000) like B. thermophilus (Desbruyeres et al. 2001), which are capable of $\mathrm{CO}_{2}$ fixation with sulfide or thiosulfate oxidation as an energy source (Cavanaugh 1983; Nelson et al. 1995). Other species, including B. childressi host only methanotrophic symbionts which use methane both as a carbon and an energy source (Childress et al. 1986; Barry et al. 2002; Pimenov et al. 2002; DeChaine and Cavanaugh 2006; Fujiwara et al. 2000). Other mussel species such as B. aff. boomerang and B. azoricus host both types of bacteria (Fisher et al. 1993; Distel et al. 1995; Robinson et al. 1998; Fiala-Médioni et al. 2002). Recently, four symbionts were discovered in B. heckerae (Fisher et al. 1993) and, in a small Idas mussel, six distinct bacterial 16S rRNA phylotypes were identified (Duperron et al. 2008). Previous immunological studies and enzyme assays have confirmed the presence of dual symbionts in both B. azoricus and B. aff. boomerang. In particular, ATP sulfurylase which indicates the potential for sulfur oxidation, and particulate methane oxygenase (pmoA) which indicates the potential for aerobic methane oxidation (Fisher et al. 1987; Robinson et al. 1998; Pimenov et al. 2002), were both found in the same gill tissue of B. azoricus and B. aff. boomerang (Duperron et al. 2005, Duperron et al. 2007). This dual symbiosis provides the mussels with two distinct sources of energy and carbon, which allows them flexibility and adaptability to their fluctuating environments (Distel et al. 1995). Endosymbiosis of chemoautotrophic bacteria in mussels plays a key-role in the ecology and biogeochemistry of deep-sea hydrothermal vents and cold seeps. Symbionts derive energy by oxidizing reduced compounds (e.g., sulfide, methane, hydrogen), which enable them to fix inorganic carbon providing nutrition to their hosts (Felbeck et al. 1981; Childress et al. 1986, 1991; Guirgis and Childress 2006). The nutritional role of bacteria has been estimated using stable isotope analysis in B. heckerae (Van Dover et al. 2003), B. brooksi and B. childressi (Duperron et al. 2007; Olu-Leroy et al. 2007), B. azoricus (Riou et al. 2010) and recently in B. aff. boomerang (Duperron et al. 2011). The bacteria are transmitted horizontally between mussels and have not yet been cultured outside of their hosts limiting the study of these symbiotic chemosynthetic bacteria (Le Pennec et al. 1988; Won et al. 2003; Salerno et al. 2005; Kàdàr et al. 2005) 
Several studies have been conducted that link symbiont ratios to the local environment parameters. The relative abundance of each symbiont is influenced by the hydrothermal fluid characteristics, especially methane and sulfide concentrations. Recently, symbiont ratios and metabolic gene expression were shown to vary significantly among specimens of $B$. azoricus from two contrasted hydrothermal vent sites, Menez Gwen and Rainbow. Specimens of $B$. azoricus from Rainbow (a hydrothermal site rich in methane) had a high concentration of methane oxidizing (MOX) bacteria and a high level of pmoA expression compared to Menez Gwen mussels (a hydrothermal site rich in sulfide), which showed a greater abundance in sulfur-oxidizing (SOX) bacteria and higher level of ATP sulfurylase gene expression (Boutet et al. 2011). In another study, a lower abundance of MOX symbionts was detected in mussels from Lucky Strike compared to Menez Gwen individuals using TEM micrographs analysis (Fiala-Médioni et al. 2002). Using a fluorescence in situ hybridization protocol coupled with 3-dimensional reconstruction of bacteriocyte sections (3D FISH), Halary et al (2008) also demonstrated that specimens of $B$. azoricus from different aggregates of animals within a single site varied in their symbiont abundances. On the contrary B. aff. boomerang collected from different mussel-aggregates within the giant cold seep pockmark REGAB (800m in diameter) showed a relatively homogenous symbiont ratios (Duperron et al. 2011). The two latter studies aimed at understanding the mechanisms developed by endosymbiont bacteria to adapt in response to changing environmental parameters. However, our understanding of the inter- and intra-site variability of the mussel symbiont ratios in contrasting ecosystems is poor. To explore this variability, we compared symbiont ratios and gene expression in two Bathymodiolus species from different habitats (vents/seeps), and from different sites within each habitat. We investigated the variability of their relative abundance and the gene expression of both symbionts in the two mussel species using real time PCR and we applied the FISH technique for a visual confirmation of the bacterial dominance in the mussel gills.

\section{Material and methods}

\subsection{Animal collection}

B. azoricus individuals were sampled at two vent fields: Menez Gwen (MG: $37^{\circ} 50^{\prime} \mathrm{N}, 31^{\circ} 31^{\prime}$ W, 830m depth; $\mathrm{n}=33$ ), and Lucky Strike (LS: $37^{\circ} 17^{\prime} \mathrm{N}, 32^{\circ} 28^{\prime} \mathrm{W}, 1700 \mathrm{~m}$ depth; $\mathrm{n}=22$ ) in the Azores region of the Mid-Atlantic Ridge using the ROV (Remotely Operated Vehicle) Victor 6000 operated from the ship N/O Pourquoi Pas? during the BIOBAZ cruise in July 
2011. B. aff. boomerang specimens were collected at three sampling areas, W01 ( $\mathrm{n}=28)$, W02 $(n=43)$ and NW $(n=27)$ from the cold seep pockmark REGAB $\left(5^{\circ} 47.9^{\prime} \mathrm{S}, 9^{\circ} 42.7^{\prime} \mathrm{E}, 3170 \mathrm{~m}\right.$ depth) in the Gulf of Guinea using the ROV Victor 6000 operated from the ship N/O Pourquoi Pas? during the West African Cold Seeps (WACS) oceanographic cruise in JanuaryFebruary 2011. Available physical and chemical characteristics for the sites: LS, MG and REGAB are listed in Table 1. Mussels were collected in thermally insulated boxes containing bottom seawater, brought on board by the ROV, and immediately placed in a cold room at $4^{\circ} \mathrm{C}$. Gills, mantle and adductor muscle were then dissected and frozen in liquid nitrogen. An additional piece of gill was sampled for FISH fixation in cold $4 \%$ paraformaldehyde in filtered seawater and stored 4 hours at $4^{\circ} \mathrm{C}$. Gills were then rinsed in filtered seawater and dehydrated in graded ethanol concentrations. They were stored in absolute ethanol at $4{ }^{\circ} \mathrm{C}$ for transportation back to the laboratory. Mussel shells were measured for each sampled individual. The shell lengths differed between the specimens from the two species: $B$. aff. boomerang (50 to $160 \mathrm{~mm})$ and B. azoricus $(53-96 \mathrm{~mm})$.

\subsection{Relative quantification of symbiont ratios and gene expression}

Genomic DNA from mussel and bacteria were extracted together from gill tissue using a CTAB/PVP extraction procedure (2\% CTAB, $1 \%$ PVP, $1.4 \mathrm{M} \mathrm{NaCl}, 0.2 \%$ beta-mercaptoethanol, $100 \mathrm{mM}$ TrisHCl pH8, $0.1 \mathrm{mg} . \mathrm{mL}-1$ proteinase $\mathrm{K}, 1 \mathrm{mg} . \mathrm{mL}-1$ lysozyme). After complete digestion of the tissues $\left(1 \mathrm{~h}\right.$ at $\left.60^{\circ} \mathrm{C}\right)$, the mixture was incubated with $1 \mu 1$ of RNase for $30 \mathrm{~min}$ at $37^{\circ} \mathrm{C}$. An equal volume of chloroform-isoamyl alcohol (24:1) was then added and the tubes were slowly mixed by inversion for $3 \mathrm{~min}$ before a centrifugation at 14,000 rpm at $4^{\circ} \mathrm{C}$ for $10 \mathrm{~min}$. The supernatant was collected in a fresh tube, and DNA was precipitated with $2 / 3$ volume of cold isopropanol $\left(1 \mathrm{~h}\right.$ at $\left.-20^{\circ} \mathrm{C}\right)$. The DNA pellet was recovered by centrifugation at $14,000 \mathrm{rpm}$ at $4{ }^{\circ} \mathrm{C}$ for $20 \mathrm{~min}$, washed with $75 \%$ cold ethanol, air-dried and re-suspended in $200 \mu 1$ of sterile water. The relative ratio of symbionts in both mussel species was estimated by real-time PCR amplification using 16S specific primers (Table 3) designed according to the probes previously developed for FISH analysis (Duperron et al. 2006). All experiments were carried out using a Chroma4 thermal cycler (Bio-Rad Laboratories, Inc. Hercules, CA) and $1 \times$ ABsolute ${ }^{\mathrm{TM}} \mathrm{QPCR}$ SYBR ${ }^{\circledR}$ Green mix (ABgene, Epsom, UK), $70 \mathrm{nM}$ of each primer, and diluted DNA (2.5 $\mathrm{ng}$ in a final volume of $10 \mu \mathrm{l})$. A $120 \mathrm{bp}$-fragment of cytosolic malate dehydrogenase gene (MDH) from the host was used as an internal PCR control. The relative ratio of each symbiont type was estimated by the comparative $\mathrm{Ct}$ method formula: $\mathrm{RQ}=2^{-\Delta \mathrm{Ct}}$, with $\Delta \mathrm{Ct}=\mathrm{Ct} 16 \mathrm{~S}-\mathrm{CtMDH}$. 
The expression of functional genes that are specific for a given metabolic pathway can be considered as an appropriate tool for investigating the metabolic potential of an organism, and can be an indicator of its physiological activity. In this study, we choose to analyze the expression of two bacterial genes, the ATP-sulfurylase (specific of the SOX metabolism) and the pmoA gene, which encodes for the particulate methane mono-oxygenase subunit-A (specific of the MOX metabolism). Using gill tissue, total RNA for both mussels and bacteria were extracted together using the Tri-Reagent (Invitrogen) according to the manufacturer's instructions. Five $\mu \mathrm{g}$ of total RNA was reverse-transcripted using M-MLV reversetranscriptase (Promega, Madison, WI), random hexamers (Promega) and an anchor-oligo(dT) primer (5'-CGCTCTAGAACTAGTGGATCT-3'). The relative gene expression of symbionts in both mussel species was estimated by real time PCR amplification using specific ATPsulfurylase and pmoA-primers (Table 2; GenBank accession numbers AB178052 and AY945761, respectively). A volume of $4 \mu \mathrm{l}$ of each diluted reverse transcription product (1:200 dilution) was subjected to real-time PCR in a final volume of $10 \mu 1$ containing $70 \mathrm{nM}$ of primers and $1 \times \mathrm{ABsolute}^{\mathrm{TM}}$ QPCR SYBR ${ }^{\circledR}$ Green Mix (ABgene). The amplification was carried out as follows in triplicates: initial enzyme activation at $94^{\circ} \mathrm{C}$ for $15 \mathrm{~min}$, then 40 cycles of $94^{\circ} \mathrm{C}$ for $15 \mathrm{sec}$, and then $60^{\circ} \mathrm{C}$ for $1 \mathrm{~min}$. A fragment of ribosomal protein $\mathrm{L} 15$ gene (RpL15) from the host was used as an internal PCR control (Table 3). Relative expression of each gene was calculated according to the comparative $\mathrm{Ct}$ method using the formula: $\mathrm{RQ}=2^{-}$ $\Delta \mathrm{Ct}$ with $\Delta \mathrm{Ct}=\mathrm{CtATPsulfur}$ or CtpmoA $-\mathrm{CtRpL} 15$.

\subsection{Statistical Analysis}

Data from quantitative real-time PCR experiments were tested for normality using the Shapiro test, and differences in bacteria ratios and gene expression level were analyzed for significance with a Welch t-test in the R Studio software (RStudio 0.96.122 Version, 2012). Boston, http://www.rstudio.org/. Differences were considered statistically significant when $\mathrm{p} \leq 0.05$.

\subsection{In situ hybridization (FISH)}

222 Based on the results of SOX and MOX ratios, we chose 3 samples showing a high symbiont 223 ratio, and three samples showing a low symbiont ratio for each species previously fixed for 224 FISH. The gills embedded in paraffin were cut at $6 \mu \mathrm{m}$ on a Leica, RM2245 microtome 225 (Germany). The sections were mounted on Super Frost slides (Euromedex, France) pre-coated 

235

with Biobond (Euromedex, France). The slides were dewaxed and the gill tissue rehydrated in a decreasing ethanol series. Hybridization was performed in a buffer composed of $(0.18 \mathrm{M}$ $\mathrm{NaCl}, 0.02 \mathrm{M}$ Tris- $\mathrm{HCl}, 0.05 \% \mathrm{SDS}$ ). To stain the symbionts, two probes were used: the MOX-specific probe ImedM-138 (5'-ACCATGTTGTC CCCCACTAA-3') labeled with Cy3 (green), and the SOX-specific probe BangT-642 (5'-CCTATACTCTAGCTTGCCAG-3') labeled with Cy5 (red) (Amann et al. 1990; Duperron et al. 2005, Duperron et al. 2008, 232 Duperron et al. 2011). The sections were incubated with $50 \mathrm{ng}$ of each probe for hybridization 233 in a $30 \%$ formamide buffer, for $3 \mathrm{~h}$ at $46^{\circ} \mathrm{C}$ in pre-heated moisture chambers. After 234 hybridization, the samples were washed twice in a solution containing $(0.04 \mathrm{M} \mathrm{NaCl}, 0.04 \mathrm{M}$

\section{Results}

\subsection{Relative quantification of symbiont ratios}

The results show that the relative abundance of symbiont ratios and gene expression were normally distributed for each sample tested in this study. The SOX and MOX ratios determination in the two mussel species from the various sites at vents or at seeps are shown in Fig. 1.

\subsubsection{Variation in SOX}

The Welch t-test showed no significant difference between SOX symbiont ratio quantified in specimens from W01 $(\mathrm{RQ}=312.0 \pm 41.7)$ compared to specimens from W02 and NW, $(\mathrm{t}=1.93$, $p$-value $=0.059$ and $\mathrm{t}=-0.8, p$-value $=0.40$, respectively), but there was a significant difference in SOX ratio between specimen from $\mathrm{W} 02$ and $\mathrm{NW}(\mathrm{t}=-3.42, p$-value=0.001). Mussels collected at NW had a significantly higher SOX level $(\mathrm{RQ}=355.6 \pm 32.7)$ compared to mussels collected at W02 (RQ = 222.0 \pm 22.5$)$ (Fig.1). No significant differences were detected for SOX ratio between B. azoricus populations from the two vent sites, LS (RQ = 301.2 \pm 34.8 ) and $\mathrm{MG}(\mathrm{RQ}=355.7 \pm 80.4)(\mathrm{t}=-0.63, p$-value=0.53) $($ Fig.1 $)$. 


\subsubsection{Variation in MOX ratio}

Samples collected from the three REGAB sites exhibited similar MOX ratio (Fig. 1) with RQ values at $384.1 \pm 49.4,273.8 \pm 37.4$ and $301.3 \pm 20.9$ for NW, W01 and W02 respectively. These relative quantities were comparable to those found for SOX ratio. No significant differences were detected for MOX ratio between the two populations from LS (RQ = 38.2 \pm 4.4$)$ and MG $(\mathrm{RQ}=33.6 \pm 3.8)(\mathrm{t}=0.82, p$-value=0.42) (Fig. 1) but these relative quantities were much lower than those found for B. azoricus SOX ratio ( $\mathrm{t}=6.05$, $p$-value $=1.358 \mathrm{e}-07)$ (Fig. 1).

\subsection{Relative quantification of symbiont gene expression}

\subsubsection{Variation in ATP sulfurylase gene expression}

Using real-time PCR, no significant difference was detected $(\mathrm{t}=0.53$ and $p$-value $=0.59)$ in symbiont-specific gene expression of ATP-sulfurylase between W01 and W02, but significant differences were found between W01 and NW ( $\mathrm{t}=2.77$ and $p$-value=0.01), and between W02 and NW ( $\mathrm{t}=3.14$ and $p$-value=0.003). Mussels collected at NW had a lower ATP-sulfurylase gene expression than the populations from W01 and W02 (Fig. 2). There was no significant difference of symbiont gene expression of ATP-sulfurylase between the two vent fields MG and LS ( $\mathrm{t}=-0.90$ and $p$-value=0.36) (Fig. 2).

\subsubsection{Variation in pmoA gene expression}

The pmoA gene encodes the active site of the pMMO (membrane-bound methane monooxygenase) enzyme. The expression level of pmoA was generally very low in both species (Fig. 2, note scale difference) with higher values for B. azoricus vs B. aff. boomerang. Samples collected from the REGAB sites had similar levels of pmoA expression: 0.0011, 0.0035, and 0.162 at NW, W01, and W02 respectively (Fig. 2). No significant differences were found in the expression of the symbiont-specific pmoA gene between the two vent fields MG (RQ = 2.00) and LS (1.21) ( $\mathrm{t}=-1.53$ and $p$-value=0.13) (Fig. 2).

\subsection{Comparative analysis of symbiont ratios and gene expression in two mussel species} A comparative analysis of symbiont ratios revealed similar SOX ratio $(\mathrm{t}=-0.94$ and $p$ value $=0.35)$, but a significant difference in MOX ratio $\left(\mathrm{t}=14.22\right.$ and $p$-value $\left.<2.2 \mathrm{e}^{-16}\right)$ between the two mussels species. The comparatively larger B. aff. boomerang species (shell length between 50 and $160 \mathrm{~cm}$ ) had markedly higher MOX ratio (316.24 \pm 19.6 ) (Fig. 1), but lower ATP-sulfurylase $(3.04 \pm 0.74)$ and pmoA $(0.07 \pm 0.05)$ gene expression, compared to the smaller species B. azoricus (shell length between 53 and $96 \mathrm{~cm}$ ), with values of $(35.43 \pm 2.8,46.42 \pm 7.9$ 

308

and 1.69 \pm 0.29 , for MOX ratio, ATP-sulfurylase and pmoA gene expression respectively (Fig. 2).

\subsection{FISH -In situ hybridization}

Fluorescence in situ hybridization of oligonucleotide probes to 16S RNA was used to identify both MOX and SOX symbiont bacteria in gills of Bathymodiolus mussels (Fig. 3). MOX dominated the gills of $B$. aff. boomerang and colonized the basal regions of the bacteriocytes (Fig. 3 A, B), whereas they appeared faintly in B. azoricus (Fig. 3 C, D). In both Bathymodiolus species, SOX were always found in the apical parts of the bacteriocytes and were the most abundant symbiont in the gills of B. azoricus (Fig. $3 \mathrm{C}, \mathrm{D}$ ). The evidence from in situ hybridization shows that B. aff. boomerang from the deeper REGAB site had obviously a greater symbiont ratio compared to B. azoricus (Fig. 3).

\section{Discussion:}

\subsection{Use of real time PCR to estimate symbiont ratios}

307 Relative or absolute quantification of symbiotic bacteria is necessary to understand the dynamics of the symbiotic associations between chemoautotrophic bacteria (methanotrophs and thiotrophs) and Bathymodiolus mussels. Previous microscopic studies have attempted to quantify the relative abundance of each bacterial type (Salerno et al. 2005). Fiala-Médioni et al (2002) qualitatively identified two symbiotic bacteria morphotypes in the gills of $B$. azoricus and B. heckerae (a species living in cold seeps) using transmission electron microscopy. Halary et al (2008) and Duperron et al (2011) used 3D-FISH to quantify the volume occupied by different symbionts in bacteriocytes from B. azoricus and B. aff. boomerang. The 3D-FISH technique is based on fluorescence in situ hybridization and image analysis. The main limitation of microscopy techniques in quantification is the fact that they do not estimate the total volume of symbionts in the entire gill of a specimen, but only in a few thin section of this gill (Halary et al., 2008). Evidence for the activity of both sulfuroxidizing and methane-oxidizing metabolic pathways has also been reported in B. azoricus (Fiala-Médioni et al. 2002). Regarding the stability of bacterial mRNA, a previous study conducted on $B$. puteoserpentis (a vent species very close to $B$. azoricus) evidenced that the half-life of pmoA mRNA was long, ranging from a few hours to several days (Wendeberg et al. 2012). Deana and Belasco (2005) have shown that while bacterial mRNAs are actively 
translated, they are very stable in comparison with their non-translated counterparts. In our study, mussels are brought on board and dissected within 2 to 6 hours after sampling on the bottom, optimizing the quality of mRNA. Indeed, using qPCR on DNA and RNA extracted from a whole piece of gill, we are not able to take into account the local heterogeneity of the symbiont distribution within each gill filament, but we generate a better estimation of the relative ratio between both symbionts. In their study, Wendeberg et al (2012) localized pmoA and aprA (encoding subunit A of the dissimilatory adenosine-5'-phosphosulfate-reductase which is involved in the metabolism of the SOX symbiont). These authors evidenced gene expression by FISH and showed that symbionts exhibited a stronger gene expression in bacteriocytes close to the frontal ciliated surface at the posterior ends of the infra-branchial chamber compared to the anterior gill ends. These authors also observed a high variability in mRNA expression between samples that could reflect local modifications of the environmental conditions.

In their study dedicated to the characterization of the SOX-symbiont population in the bivalve Codakia orbicularis, Caro et al (2007) evidenced the existence of different subpopulations characterized by various numbers of genome-copies ranging from haploid to tetraploid stages. The multigenomic state of bacteria has been considered to be a signature of their ability for rapid cell division when nutrients become available (Thorsen et al. 1992). The ploidy degree has never been addressed in the symbiont of any Bathymodiolus species, so it is at present impossible to know if one or both symbiont exhibit variable numbers of genome copies and in which proportion. Our PCR approach does not allow to address this question since we do not have any way to quantify the gill cells, nor the bacterial cells and then subsequently establish a correlation between $\mathrm{C}(\mathrm{t})$ values and cell numbers. The observation of polyploidy made by Caro et al (2007) could have an impact on what we have considered as the symbiont ratio, in such a way that the real number of bacterial cells could not be directly correlated with the $\mathrm{C}(\mathrm{t})$ value. Without any additional information, we assume that even this could happen in mussel bacteriocytes, as the medium ratio of cells showing the different polyploidy status is quite similar in all samples. Our ratios show differences between individuals, even if not strictly correlated to an exact cell number. In previous studies using FISH as a tool for symbiont ratios estimates, the question of the number of genome copies is not addressed either although it might affect fluorescence intensity. Overall, FISH techniques give a snapshot of a gill section, with precise and accurate spatial information but inadequate quantitative estimates of relative abundance in symbiont ratio. Moreover FISH or TEM techniques are time-consuming and only a limited number of samples/individuals can be 
analyzed. Applying qPCR is considerably faster and cheaper, and allows taking into account a large number of individuals and their natural variation. Therefore, the use of q-PCR approach to estimate the relative abundance of symbionts in the mussel gills has to be considered as complementary to other methods such as 2D or 3D FISH and TEM micrographs. Furthermore, the expression of additional metabolic genes has to be considered to better characterize the physiological status of symbionts. Genomes of both B. azoricus symbionts genomes are presently being sequenced and annotated and this new information should help resolve these problems.

\subsection{Variation in SOX ratio and ATP sulfurylase gene expression}

Mussels at the REGAB site were mostly concentrated in two areas: W01 and W02 (corresponding to M1 and M2 as described by Marcon et al. 2013). In our study, we focused on mussels from three areas W01 and W02 described by Duperron et al (2005) and Olu-Leroy et al (2007) and NW (NorthWest). We report the first data for symbiont ratios and gene expression in Bathymodiolus specimens from the NW habitat.

The short distance that separate W02 from W01 (around 100 meters) may partly explain the similar SOX ratio and ATP-sulfurylase expression in mussels from those areas, and may also support the hypothesis that mussels from W01 and W02 are exposed to similar environmental conditions. This is in agreement with previous studies conducted on mussels from the REGAB site that showed no significant difference in SOX abundance in gills of $B$. aff. boomerang collected in three areas separated by less than thirty meters (Duperron et al. 2011). The NW area is located 140 meters from W01 and at 190 meters from W02. Mussels from NW seem to have a high SOX ratio and a low ATP-sulfurylase expression compared to mussels from W02. These differences are likely the result of local differences in environmental conditions specific to $\mathrm{NW}$, as well as overall varying conditions at the REGAB pockmark. Ondréas et al (2005), Charlou et al (2004) and Olu-Le Roy et al (2007) reported that methane concentrations in the giant REGAB pockmark decrease from the center to the periphery. Our results on the MOX and SOX symbionts in the mussels lead us to suggest that, contrary to methane, sulfide concentrations increase in the center of REGAB pockmark outward to the periphery. We also hypothesize that mussels from NW are exposed to more transient sulfide fluxes than mussels from W02. According to Charlou et al (2004), the methane concentration $(13.85 \mu \mathrm{l} / \mathrm{l})$ observed in an area close to NW was much lower than

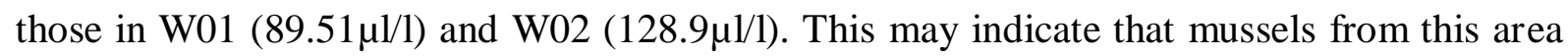
rely more on sulfide than methane as an energy and carbon source to compensate for the 
lower concentration of methane, Sulfide probably represents an important secondary energy source for mussels from the NW. This implies that fluid flow is intense but different in the three areas. The sulfide and methane concentrations were identified as important factors influencing the symbiont bacteria quantities in gills of hydrothermal Bathymodiolus mussels (Fiala- Médioni et al. 2002; Duperron et al. 2006), but the link between symbiont ratios and environmental conditions is complex as evidenced by the fact that the SOX symbiont ratio is similar in B. azoricus inhabiting two physically and chemically contrasting vent fields, LS and MG. Our results suggest that the variation in sulfide availability in the cold seep areas W01/W02 and NW impacted the SOX symbiont ratio in B. aff. boomerang at a short spatial scale.

\subsection{Variation in MOX ratio and pmoA gene expression}

Mussels from W01, W02 and NW have statistically similar MOX ratio and pmoA expression levels indicating that methane concentrations could be similar in these areas. The three (smaller pockmark) sites sampled are located in the center of REGAB giant pockmark where the methane flux is the highest and methane fluxes have been observed in all mussel beds (Ondréas et al. 2005; Olu-Le Roy et al. 2007; Marcon et al. 2013). MOX ratio and pmoA expression were also similar for B. azoricus specimens from two hydrothermal sites, LS and MG. We have no specific measurements of sulfide and methane in the vicinity of the $B$. azoricus mussel beds sampled, but as previously reported, reduced concentrations of sulfide were measured in fluids at MG ranging from 0.6 to $3.3 \mathrm{mM}$, and at $\mathrm{LS}$ from 1.3 to $1.82 \mathrm{mM}$ while methane concentrations of up to $0.52 \mathrm{mM}$ and $1.7 \mu \mathrm{M}$ were measured at LS and MG respectively (Douville et al. 2002; Charlou et al. 2002, Chralou et al. 2004). These findings are in agreement with our results and could explain the predominance of SOX thiotrophic symbionts in the gills of all specimens of B. azoricus.

\subsection{Comparative analysis of symbiont ratios and gene expression between species}

In the present study, we report the first attempt to compare symbiont ratios and gene expression in the gills of two Bathymodiolus species from contrasting environments: hydrothermal vents and cold seeps. Our results indicate that the MOX ratio is higher in the gills of $B$. aff. boomerang compared to B. azoricus. The dominance of MOX is not surprising since methane concentrations are significantly higher in cold seeps. Mussel beds from the three areas within REGAB pockmark showed obvious pulses of free methane gas into the water column, which could result in an appreciable variability in the concentration of gas 
(Boetius and Suess 2004; De Beer et al. 2006; Niemann et al. 2006). These observations support the hypothesis that relative abundance of symbiont bacteria could be significantly influenced by environmental conditions (Fiala- Médioni et al. 2002; Duperron et al. 2006). The average ratio and gene expression for each symbiont was significantly different between species. B. aff. boomerang from deeper sites $(3170 \mathrm{~m})$ exhibits a higher symbiont ratio, but associated with the lowest gene expression. Generally, mussels collected from shallow water benefit from a higher particulate flux (Riou et al. 2010) which is the case for MG and LS populations that are located at 830 and 1700 meters depth respectively. The presence of particle flux suggests that these mussels could rely less on symbionts to meet their carbon needs. At the contrary, in the deeper sites, particles are less accessible to mussels increasing the dependence of mussels on their symbionts. Surprisingly, we observed that gene expression of both ATP-sulfurylase and pmoA are significantly higher in B. azoricus individuals suggesting that gene expression in both species can be modulated by various factors, but also that there is no evident correlation between symbiont ratios and gene expression at least for these metabolisms. Evidence from in situ hybridization experiments confirm that symbiont bacteria are abundantly expressed in gills of $B$. aff. boomerang. In contrast, less symbiont bacteria were detected in B. azoricus. Our qPCR and FISH results are congruent on this aspect and both indicate that chemosynthetic bacteria make a substantial contribution to the nutrition of the B. aff. boomerang.

For both species, size dependent variations on symbiont ratios and gene expression were not significant as found by Duperron et al (2011). Martins et al (2008) showed that small individuals of $B$. azoricus mussels were strongly dependent on filter-feeding while larger mussels obtained a significant portion of their energy from endosymbiosis, suggesting that symbiont ratios could increase with age. We did not observe such correlation between symbiont ratios and mussel size in our B. azoricus sample but this might be due to the fact that very small specimens were not present in our collection.

To conclude, we have presented a comparative analysis of symbiont ratios and gene expression in the gills of two Bathymodiolus species to improve the understanding of interand intra-site variability observed in mussels from contrasting environments. Symbiont ratios in the gills of mussels reflect the environmental levels of methane and sulfide. $B$. aff. boomerang from a methane rich environment (cold seeps) showed a significantly higher relative abundance of MOX, and $B$. azoricus from a sulfide rich environment (hydrothermal vent) showed a significantly higher relative abundance of SOX. We also evidenced that symbiont ratios (based on 16S DNA qPCR assay) is not strictly correlated to gene expression 
460 for ATP-sulfurylase and pmoA (based on mRNA qPCR assay). A complementary work based

1 461 on the use of more genes from metabolic pathways has to be performed to further explore this 3462 relation. 


\section{Acknowledgements}

We thank the crew and pilots of the NO Pourquoi Pas? and the ROV Victor 6000 for their assistance and technical support, as well as the chief scientist Dr. Karine Olu Le Roy during the cruise WACS (2011) and Dr. François Lallier, during the cruise BIOBAZ (2011). We thank Dr. Sophie Le Panse, manager of Optical Imaging Platform Merimage of the Station Biologique de Roscoff, for having introduced us (HG and AA) to the confocal microscopy. This work was funded by the Région Bretagne with the help of GIS Europole Mer (HG), and the JST/CNRS Bathymodiolus program (AT, FHL).

\section{References}

Amann R, Binder BJ, Olson RJ, Chisholm SW, Devereux R, Stahl DA (1990) Combination of 16S rRNA-targeted oligonucleotide probes withflow cytometry for analyzing mixed microbial populations. Appl Environ Microbiol 56:1919-1925

Barry JP, Buck KR, Kochevar RK, Nelson DC, Fujiwara Y, Goffredi SK, Hashimoto J (2002) Methane-based symbiosis in a mussel, Bathymodiolus platifrons, from cold seeps in Sagami Bay, Japan. Invert Biol 121:47-54

Boetius A, Suess E (2004) Hydrate Ridge: a natural laboratory for the study of microbial life fueled by methane from near-surface gas hydrates. Chemical Geology 205:291-310

Boutet I, Ripp R, Lecompte O, Dossat C, Corre E, Tanguy A, Lallier F (2011) Conjugating effects of symbionts and environmental factors on gene expression in deep-sea hydrothermal vent mussels. BMC genomics 12:530

Caro A, Gros O, Got P, De Wit R, Troussellier M (2007) Characterization of the Population of the Sulfur-Oxidizing Symbiont of Codakia orbicularis (Bivalvia, Lucinidae) by Single-Cell Analyses. Appl Environ Microbiol 73: 2101-2109

Cavanaugh CM (1983) Symbiotic chemoautotrophic bacteria in marine invertebrates from sulfide-rich habitats. Nature 302:58-61

Cavanaugh CM, McKiness ZP, Newton ILG, Stewart FJ (2006) Marine Chemosynthetic Symbioses. In: Dworkin M., Falkow S., Rosenberg E., Schleifer K.-H., Stackebrandt E. (eds) The Prokaryotes. Springer New York, New York, NY, pp 475-507

Charlou JL, Donval JP, Fouquet Y, Jean-Baptiste P, Holm N (2002) Geochemistry of high $\mathrm{H}_{2}$ 
and $\mathrm{CH}_{4}$ vent fluids issuing from ultramafic rocks at the Rainbow hydrothermal field (36² $\left.14^{\prime} \mathrm{N}, \mathrm{MAR}\right)$. Chem Geol 191:345-359

Charlou JL, Donval J, Fouquet Y, Ondreas H, Knoery J, Cochonat P, Levaché D, Poirier Y, Jean-Baptiste P, Fourré E, Chazallon B (2004) Physical and chemical characterization of gas hydrates and associated methane plumes in the Congo-Angola Basin. Chem Geol 205:405-425

Childress JJ, Fisher CR, Brooks JM, Kennicutt MC, Bidigare R, Anderson AE (1986) A Methanotrophic Marine Molluscan (Bivalvia, Mytilidae) Symbiosis: Mussels Fueled by Gas. Science 233:1306-1308

Childress JJ, Fisher CR, Favuzzi JA, Kochevar RE, Sanders NK, Alayse AM (1991) Sulfidedriven autotrophic balance in the bacterial symbiont-containing hydrothermal vent tubeworm, Riftia pachyptila Jones. Biol Bull 180:135-153

De Beer D, Sauter EJ, Niemann H, Kaul N, Foucher J-P, Witte U, Schlüter M, Boetius A (2006) In situ fluxes and zonation of microbial activity in surface sediments of the Haakon Mosby Mud Volcano. Lim Oceano 51: 1315-1331

DeChaine EG, Bates AE, Shank TM, Cavanaugh CM (2006) Off-axis symbiosis found: characterization and biogeography of bacterial symbionts of Bathymodiolus mussels from Lost City hydrothermal vents. Environ Microbiol 8:1902-1912

DeChaine EG, Cavanaugh CM (2006) Symbioses of methanotrophs and deep-sea mussels (Mytilidae: Bathymodiolinae). Molecular basis of symbiosis. Springer, pp 227-249

Desbruyères D, Biscoito M, Caprais J-C, Colaço A, Comtet T, Crassous P, Fouquet Y, Khripounoff A, Le Bris N, Olu K, Riso R, Sarradin P-M, Segonzac M, Vangriesheim A (2001) Variations in deep-sea hydrothermal vent communities on the Mid-Atlantic Ridge near the Azores plateau. Deep Sea Research Part I: Oceano Res Papers 48:1325-1346

Dickens GR (2003) Rethinking the global carbon cycle with a large, dynamic and microbially mediated gas hydrate capacitor. Earth Plan Sci Letters 213:169-183

Distel DL, Lee HK, Cavanaugh CM (1995) Intracellular coexistence of methano-and thioautotrophic bacteria in a hydrothermal vent mussel. Proc Natl Acad Sci 92:9598-9602

Douville E, Charlou J, Oelkers E, Bienvenu P, Jove Colon C, Donval J, Fouquet Y, Prieur D, Appriou $P$ (2002) The rainbow vent fluids $\left(36^{\circ} 14^{\prime} \mathrm{N}, \mathrm{MAR}\right)$ : the influence of ultramafic rocks and phase separation on trace metal content in Mid-Atlantic Ridge hydrothermal fluids. Chem Geol 184:37-48

Dubilier N, Bergin C, Lott C (2008) Symbiotic diversity in marine animals: the art of 
Duperron S, Nadalig T, Caprais J-C, Sibuet M, Fiala-Medioni A, Amann R, Dubilier N (2005) Dual Symbiosis in a Bathymodiolus sp. Mussel from a Methane Seep on the Gabon Continental Margin (Southeast Atlantic): 16S rRNA Phylogeny and Distribution of the Symbionts in Gills. Appl Env Microbiol 71:1694-1700.

Duperron S, Bergin C, Zielinski F, Blazejak A, Pernthaler A, McKiness ZP, DeChaine E, Cavanaugh CM, Dubilier N (2006) A dual symbiosis shared by two mussel species, Bathymodiolus azoricus and Bathymodiolus puteoserpentis (Bivalvia: Mytilidae), from hydrothermal vents along the northern Mid-Atlantic Ridge. Environ Microbiol 8:1441-1447

Duperron S, Fiala-Médioni A, Caprais JC, Olu K, Sibuet M (2007) Evidence for chemoautotrophic symbiosis in a Mediterranean cold seep clam (Bivalvia: Lucinidae): comparative sequence analysis of bacterial 16S rRNA, APS reductase and RubisCO genes: Symbiosis in a cold-seep lucinid. FEMS Microbiol Ecol 59:64-70

Duperron S, Halary S, Lorion J, Sibuet M, Gaill F (2008) Unexpected co-occurrence of six bacterial symbionts in the gills of the cold seep mussel Idas sp. (Bivalvia: Mytilidae). Environ Microbiol 10:433-445

Duperron S, Guezi H, Gaudron SM, Pop Ristova P, Wenzhöfer F, Boetius A (2011) Relative abundances of methane- and sulphur-oxidising symbionts in the gills of a cold seep mussel and link to their potential energy sources. Geobiology 9:481-491

Felbeck H, Childress JJ, Somero GN (1981) Calvin-Benson cycle and sulfide oxidation enzymes in animals from sulfide-rich habitats. Nature 293:291-293

Fiala-Médioni A, McKiness Z, Dando P, Boulegue J,.Mariotti A, Alayse-Danet A, Robinson J, Cavanaugh C (2002) Ultrastructural, biochemical, and immunological characterization of two populations of the mytilid mussel Bathymodiolus azoricus from the Mid-Atlantic Ridge: evidence for a dual symbiosis. Mar Biol 141:1035-1043

Fisher CR, Childress JJ, Oremland RS, Bidigare RR (1987) The importance of methane and thiosulfate in the metabolism of the bacterial symbionts of two deep-sea mussels. Mar Biol 96:59-71

Fisher CR, Brooks JM, Vodenichar JS, Zande JM, Childress JJ (1993) The Co-occurrence of Methanotrophic and Chemoautotrophic Sulfur-Oxidizing Bacterial Symbionts in a Deep-sea Mussel. Mar Ecol 14:277-289

Fujiwara Y, Takai K, Uematsu K, Tsuchida S, Hunt JC, Hashimoto J (2000) Phylogenetic characterization of endosymbionts in three hydrothermal vent mussels: influence on 
Génio L, Johnson SB, Vrijenhoek RC, Cunha MR, Tyler PA, Kiel S, Little CT (2008) New record of "Bathymodiolus" mauritanicus Cosel 2002 from the Gulf of Cadiz (NE Atlantic) mud volcanoes. J Shellfish Res 27:53-61

Geret F, Rousse N, Riso R, Sarradin PM, Cosson RP (1998) Metal compartmentalization and metallothionein isoforms in mussels from the Mid-Atlantic Ridge; preliminary approach to the fluid-organism relationship. Cah Biol Mar 39(3-4): 291-293

Geret F, Riso R, Sarradin PM, Caprais JC, Cosson RP (2002). Metal bioaccumulation and storage forms in the shrimp, Rimicaris exoculata, from the Rainbow hydrothermal field (Mid-Atlantic Ridge); preliminary approach to the fluid-organism relationship. Cah Biol Mar 43, 43- 52

German CR, Lin J (2004) The thermal structure of the oceanic crust, ridge-spreading and hydrothermal circulation: How well do we understand their inter-connections? In: German C.R., Lin J., Parson L.M. (eds) Geophysical Monograph Series. American Geophysical Union, Washington, D. C., pp 1-18

Gibson RN, Atkinson RJA, Gordon JDM (2005) Ecology of cold seep sediments: interactions of fauna with flow, chemistry and microbes. Oceano Mar Biol Annu Rev 43:1-46

Girguis PR (2006) Metabolite uptake, stoichiometry and chemoautotrophic function of the hydrothermal vent tubeworm Riftia pachyptila: responses to environmental variations in substrate concentrations and temperature. J Exp Biol 209:3516-3528

Girguis PR, Childress JJ (2006). Metabolite stoichiometry and chemoautotrophic function of the hydrothermal vent tubeworm Riftia pachyptila: responses to environmental variations in substrate concentrations and temperature. J. Exp. Biol. 209: 3516-3528

Halary S, Riou V, Gaill F, Boudier T, Duperron S (2008) 3D FISH for the quantification of methane- and sulphur-oxidizing endosymbionts in bacteriocytes of the hydrothermal vent mussel Bathymodiolus azoricus. The ISME Journal 2:284-292

Helmstetter CE, Cooper S (1968) DNA synthesis during the division cycle of rapidly growing E. coli B/r. J Mol Biol 31:507-518

Kádár E, Bettencourt R, Costa V, Santos RS, Lobo-da-Cunha A, Dando P (2005) Experimentally induced endosymbiont loss and re-acquirement in the hydrothermal vent bivalve Bathymodiolus azoricus. J Exp Mar Biol Ecol 318:99-110

Kenk VC, Wilson BR (1985) A new mussel (Bivalvia, Mytilidae) from hydrothermal vents in the Galapagos Rift zone. Malacologia 26:253-271

Kojima S (2002) Deep-sea chemoautosynthesis-based communities in the northwestern 
Pacific. J Oceano 58: 343-363

Le Bris N, Sarradin PM, Caprais JC (2003) Contrasted sulphide chemistries in the environment of $13^{\circ} \mathrm{N}$ EPR vent fauna. Deep Sea Research Part I: Oceano Res Papers 50:737-747

Le Pennec M, Diouris M, Herry A (1988) Endocytosis and lysis of bacteria in gill epithelium of Bathymodiolus thermophilus, Thyasira flexuosa and Lucinella divaricata (Bivalve, Molluscs). J Shellfish Res 7: 483-489

Levin LA (2005). Ecology of cold seep sediments: interactions of fauna with flow, chemistry, and microbes. Oceanogr. Mar. Biol. Ann Rev 43, 1-46.

Lewis KB, Marshall BA (1996). Seep faunas and the other indicators of methane-rich dewatering on New Zealand convergent margins. New Zealand J. of Geol Geophy 39, 181-200

Levin LA, Dayton PK (2009) Ecological theory and continental margins: where shallow meets deep. Trends Ecol Evol 24:606-617

Lonsdale P, Becker K (1985) Hydrothermal plumes, hot springs, and conductive heat flow in the Southern Trough of Guaymas Basin. Earth Plan Sci Letters 73:211-225

MacDonald IR, Boland GS, Baker JS, Brooks JM, Kennicutt II MC, Bidigare RR (1989) Gulf of Mexico hydrocarbon seep communities. Mar Biol 101:235-247

Marcon Y, Sahling H, Allais AG, Bohrmann G, Olu K (2013) Distribution and temporal variation of mega-fauna at the Regab pockmark (Northern Congo Fan), based on a comparison of videomosaics and geographic information systems analyses. Mar Ecol. SSN 0173-9565: 1-19.doi: 10.1111/maec.12056

Martins I, Colaço A, Dando PR, Martins I, Desbruyères D, Sarradin P-M, Marques JC, Serrão-Santos R (2008) Size-dependent variations on the nutritional pathway of Bathymodiolus azoricus demonstrated by a C-flux model. Ecol Model 217:59-71

Nelson DC, Fisher CR (1995) Chemoautotrophic and methanotrophic endosymbiotic bacteria at deep-sea vents and seeps. In Microbiology of deep-sea hydrothermal vents Karl DM (ed) Boca Raton FL:CRC Press inc pp 125-167

Nelson DC, Hagen KD, Edwards DB (1995) The gill symbiont of the hydrothermal vent mussel Bathymodiolus thermophilus is a psychrophilic, chemoautotrophic, sulfur bacterium. Mar Biol 121:487-495

Niemann H, Lösekann T, de Beer D, Elvert M, Nadalig T, Knittel K, Amann R, Sauter EJ, Schlüter M, Klages M, Foucher JP, Boetius A (2006) Novel microbial communities of the Haakon Mosby mud volcano and their role as a methane sink. Nature 443:854-858 
Olu-Le Roy K, Caprais J-C, Fifis A, Fabri M-C, Galéron J, Budzinsky H, Le Ménach K, Khripounoff A, ééas H, Sibuet M (2007) Cold-seep assemblages on a giant pockmark off West Africa: spatial patterns and environmental control. Mar Ecol 28:115-130

Ondréas H, Olu K, Fouquet Y, Charlou JL, Gay A, Dennielou B, Donval JP, Fifis A, Nadalig T, Cochonat P, Cauquil E, Bourillet JF, Moigne ML, Sibuet M (2005) ROV study of a giant pockmark on the Gabon continental margin. Geo Mar Letters 25:281-292

Pimenov NV, Kalyuzhnaya MG, Khmelenina VN, Mityushina LL, Trotsenko YA (2002) Utilization of methane and carbon dioxide by symbiotrophic bacteria in gills of Mytilidae (Bathymodiolus) from the Rainbow and Logachev hydrothermal fields on the Mid-Atlantic Ridge. Microbiology 71:587-594

Riou V, Duperron S, Halary S, Dehairs F, Bouillon S, Martins I, Colaço A, Serrão Santos R (2010) Variation in physiological indicators in Bathymodiolus azoricus (Bivalvia: Mytilidae) at the Menez Gwen Mid-Atlantic Ridge deep-sea hydrothermal vent site within a year. Mar Environ Res 70:264-271

Robinson JJ, Polz MF, Fiala-Medioni A, Cavanaugh CM (1998) Physiological and immunological evidence for two distinct C1-utilizing pathways in Bathymodiolus puteoserpentis (Bivalvia: Mytilidae), a dual endosymbiotic mussel from the MidAtlantic Ridge. Mar Biol 132:625-633

Salerno JL, Macko SA, Hallam SJ, Bright M, Won Y-J, McKiness Z, Van Dover CL (2005) Characterization of symbiont populations in life-history stages of mussels from chemosynthetic environments. Biol Bull 208:145-155

Sibuet M, Olu K (1998) Biogeography, biodiversity and fluid dependence of deep-sea coldseep communities at active and passive margins. Deep-Sea Research Part II 45:517567

Tivey MK (1995). Modeling chimney growth and associated fluid flow at seafloor hydrothermal vent sites. In Humphris SE, Zierenberg RA, Mullineaux LS, and Thomson RE. (Eds.), Seafloor Hydrothermal Systems: Physical, Chemical, Biol Geol Interac, Am.Geophys. Union, Geophys. Monogr., 91:158-177

Thorsen BK, Enger O, Norland S. Hoff KJ. (1992) Long-term starvation survival of Yersinia ruckeri at different salinities studied by microscopical and flow cytometric methods. Appl. Environ Microbiol. 58:1624-1628

Van Dover CL (2000) The ecology of deep-sea hydrothermal vents. Princeton University Press, Princeton, N.J 
Van Dover CL, Trask JL (2000) Diversity at deep-sea hydrothermal vent and intertidal mussel beds. Mar Ecol Prog Ser 195:169-178

Van Dover CL (2002) Evolution and Biogeography of Deep-Sea Vent and Seep Invertebrates. Science 295:1253-1257

Van Dover CL, Aharon P, Bernhard JM, Caylor E, Doerries M, Flickinger W, Gilhooly W, Goffredi SK, Knick KE, Macko SA, Rapoport S, Raulfs EC, Ruppel C, Salerno JL, Seitz RD, Sen Gupta BK, Shank T, Turnipseed M, Vrijenhoek R (2003) Blake Ridge methane seeps: characterization of a soft-sediment, chemosynthetically based ecosystem. Deep Sea Research Part I: Oceano Res Papers 50:281-300

Vanreusel A, Fonseca G, Danovaro R, Da Silva MC, Esteves AM, Ferrero T, Gad G, Galtsova V, Gambi C, Da Fonsêca Genevois V, Ingels J, Ingole B, Lampadariou N, Merckx B, Miljutin D, Miljutina M, Muthumbi A, Netto S, Portnova D, Radziejewska T, Raes M, Tchesunov A, Vanaverbeke J, Van Gaever S, Venekey V, Bezerra TN, Flint H, Copley J, Pape E, Zeppilli D, Martinez PA, Galeron J (2010) The contribution of deep-sea macrohabitat heterogeneity to global nematode diversity: Nematode diversity and habitat heterogeneity. Mar Ecol 31:6-20

Von Damm KL (1995) Controls on the chemistry and temporal variability of seafloor hydrothermal fluids. In: Humphris SE, Zierenberg RA, Mullineaux LS, Thomson RE (eds) Geophysical Monograph Series. American Geophysical Union, Washington, D. C., pp 222-247

Won YJ, Hallam SJ, O’Mullan GD, Pan IL, Buck KR, Vrijenhoek RC (2003) Environmental Acquisition of Thiotrophic Endosymbionts by Deep-Sea Mussels of the Genus Bathymodiolus. Appl Environ Microbiol 69:6785-6792 


\section{TABLES}

Table1: Sulfide and methane concentrations recorded in fluids at Menez Gwen and Lucky Strike. (adapted from Douville et al. 2002; Charlou et al. 2000, 2004) and methane concentration reported around mussels at three minor pockmarks within REGAB giant pockmark (Charlou et al. 2004). ND: not determined.

\begin{tabular}{|c|c|c|c|}
\hline SITES & DEPTH $(\mathbf{m})$ & H2S concentration & CH4 concentration \\
\hline LS & 1700 & $0.6-3.3(\mathrm{mM})$ & $0.52(\mathrm{mM})$ \\
\hline MG & 850 & $1.3-1.82(\mathrm{mM})$ & $1.7(\mathrm{mM})$ \\
\hline W01 & 3156 & ND & $89.5 \mu \mathrm{l} / 1$ \\
\hline W02 & 3156 & ND & $128.9 \mu \mathrm{l} / \mathrm{l}$ \\
\hline NW & 3156 & ND & $13.8 \mu \mathrm{l} / \mathrm{l}$ \\
\hline
\end{tabular}

Table 2: Primers used in real-time PCR amplification of bacteria and host gene.

\begin{tabular}{|c|c|}
\hline Genes & Primer sequence 5'-3' \\
\hline Sulfide oxidizer symbiont $16 \mathrm{~S}(\mathrm{SOX})$ & $\begin{array}{l}\text { 115F : 5'-GAGTAACGCGTAGGAATCTGC-3' } \\
\text { 193R : 5'-CGAAGGTCCTCCACTTTACTCCATAGAG-3' }\end{array}$ \\
\hline Methanotrophic symbiont 16S (MOX) & $\begin{array}{l}\text { 515F: 5'-GTGCCAGCMGCCGCGGTAA-3' } \\
\text { 845R: 5'-GCTCCGCCACTAAGCCTATAAATAGACC-3', }\end{array}$ \\
\hline $\begin{array}{l}\text { Cytosolic malate } \\
\text { dehydrogenase (host) (MDH) }\end{array}$ & $\begin{array}{l}\text { For: 5'- ATGGAGGAAAGAGATATGGCACTGAGCGT-3' } \\
\text { Rev: 5'-TAACATTAAACATAGCCTAGGAACCTAATG-3' }\end{array}$ \\
\hline ATP sulfurylase & $\begin{array}{l}\text { For: 5' - GTGCGTGATGCCGCTATCCGCACCATG-3' } \\
\text { Rev : 5'-GGTCCGGCATAGAGCATGTCAAACGGATA-3' }\end{array}$ \\
\hline $\begin{array}{l}\text { particulatemethanemonooxygenasesubunit A } \\
\text { (PMOA) }\end{array}$ & $\begin{array}{l}\text { For : 5'-GAGTGGATTAACAGATATTTGAACTTCTGG-3' } \\
\text { Rev : 5'-CATACCACCAACAACAGCTGTAAGTACAAA-3' }\end{array}$ \\
\hline $\begin{array}{l}\text { ribosomal protein L15 gene } \\
\text { (RPL15) }\end{array}$ & $\begin{array}{l}\text { For 5'-TATGGTAAACCTAAGACACAAGGAGT-3' } \\
\text { Rev 5'-TGGAATGGATCAATCAAAATGATTTC-3' }\end{array}$ \\
\hline
\end{tabular}




\section{FIGURES}

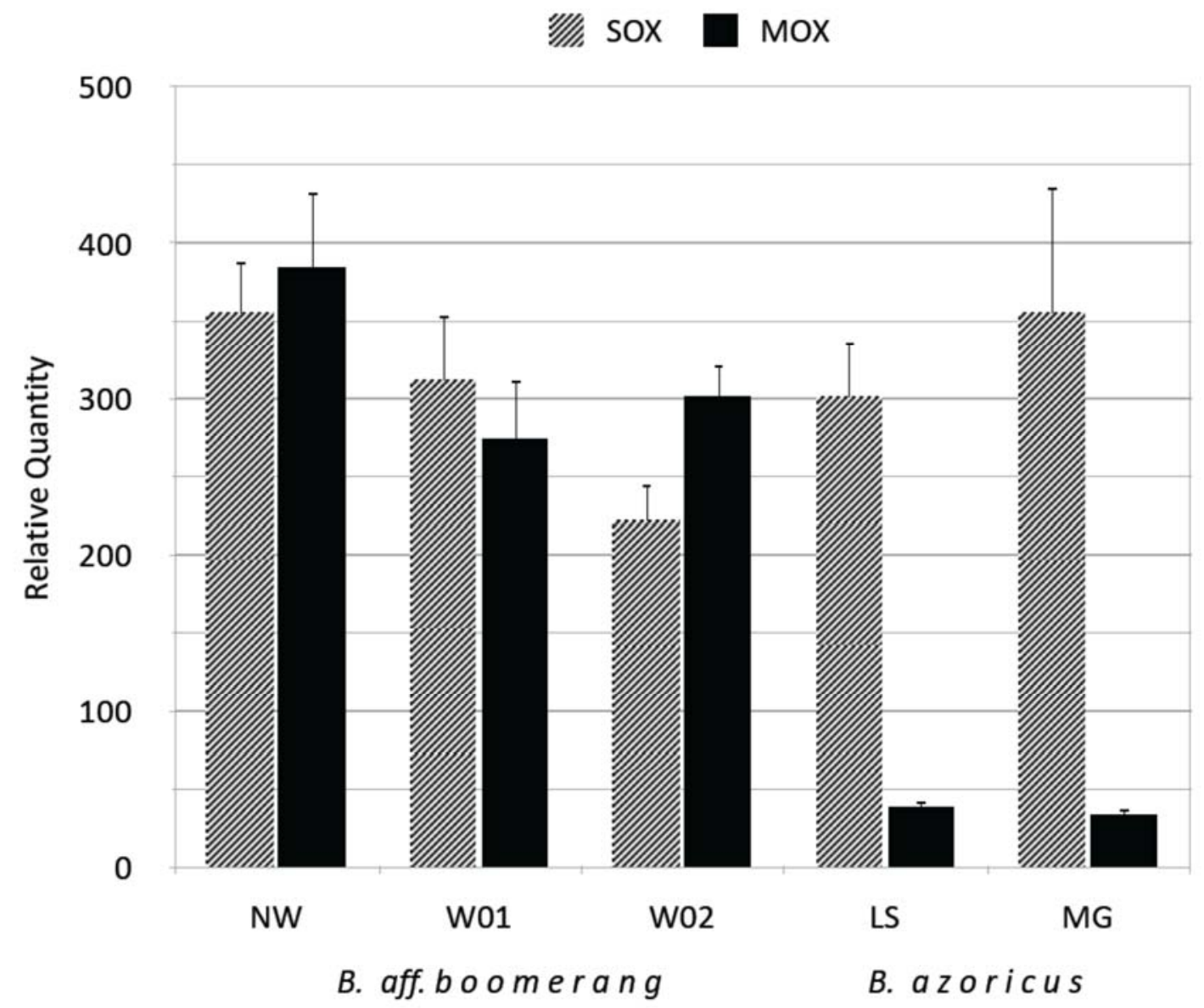

Fig. 1 Relative quantification of thiotrophic symbiont (SOX) and methanotrophic symbiont (MOX) in gills of B. aff. boomerang collected from three sampling areas, W01 (n=28), W02 $(\mathrm{n}=43)$ and NW (n=27) and B. azoricus collected from two vent fields, MG $(\mathrm{n}=33)$ and LS $(n=22)$. 
W// ATP-S $\mathbf{p m o A}$

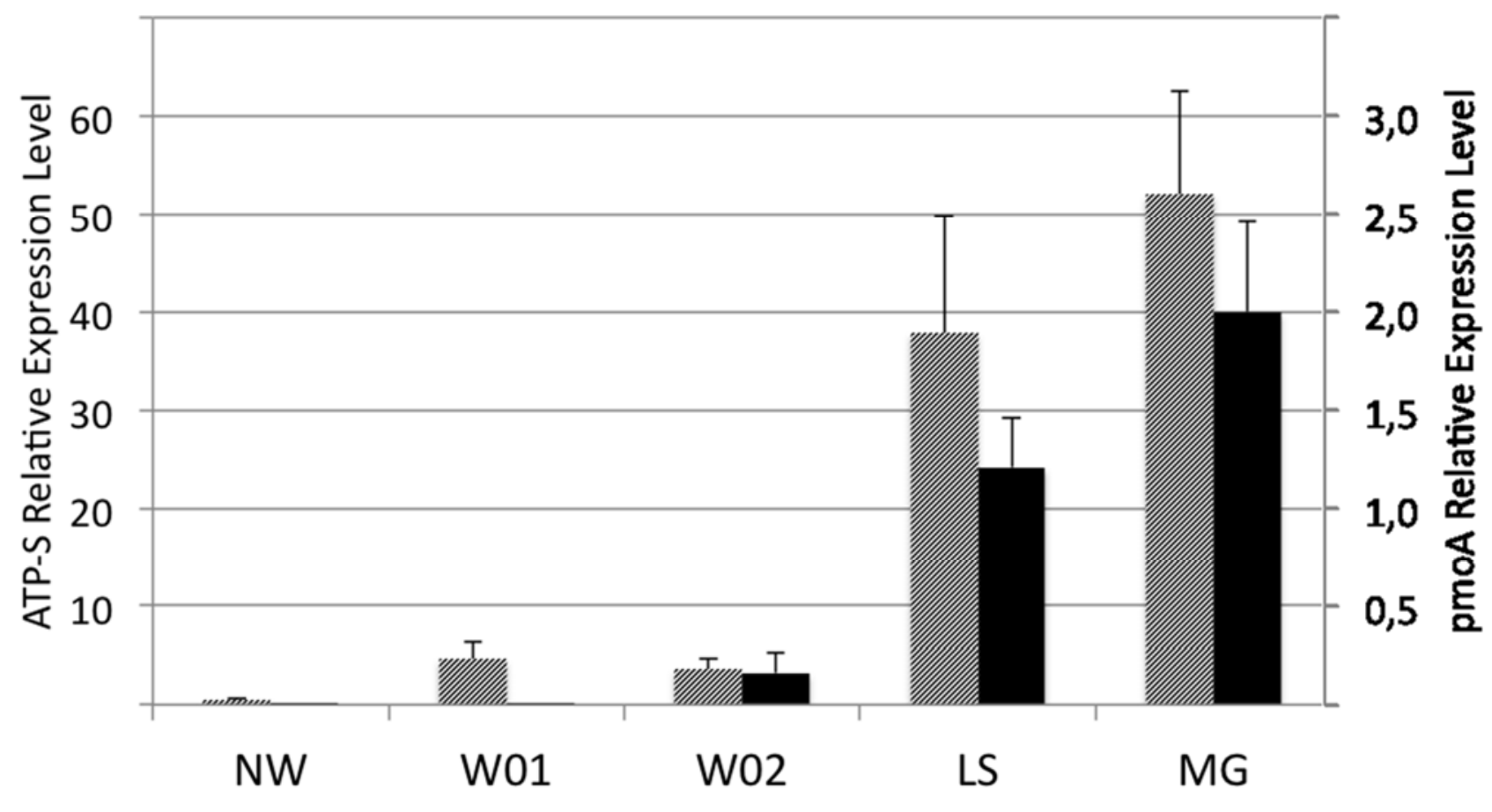

B. aff. boomerang

B. azoricus

Fig. 2 Relative quantification of ATP sulfurylase (ATP-S) and particular methane oxygenase, subunit A (pmoA) gene expression in gills of B. aff. boomerang collected from three cold seep sampling areas, W01 $(\mathrm{n}=28)$, W02 $(\mathrm{n}=43)$ and NW $(\mathrm{n}=27)$, and B. azoricus collected from two vent fields, $M G(n=33)$ and $L S(n=22)$. 


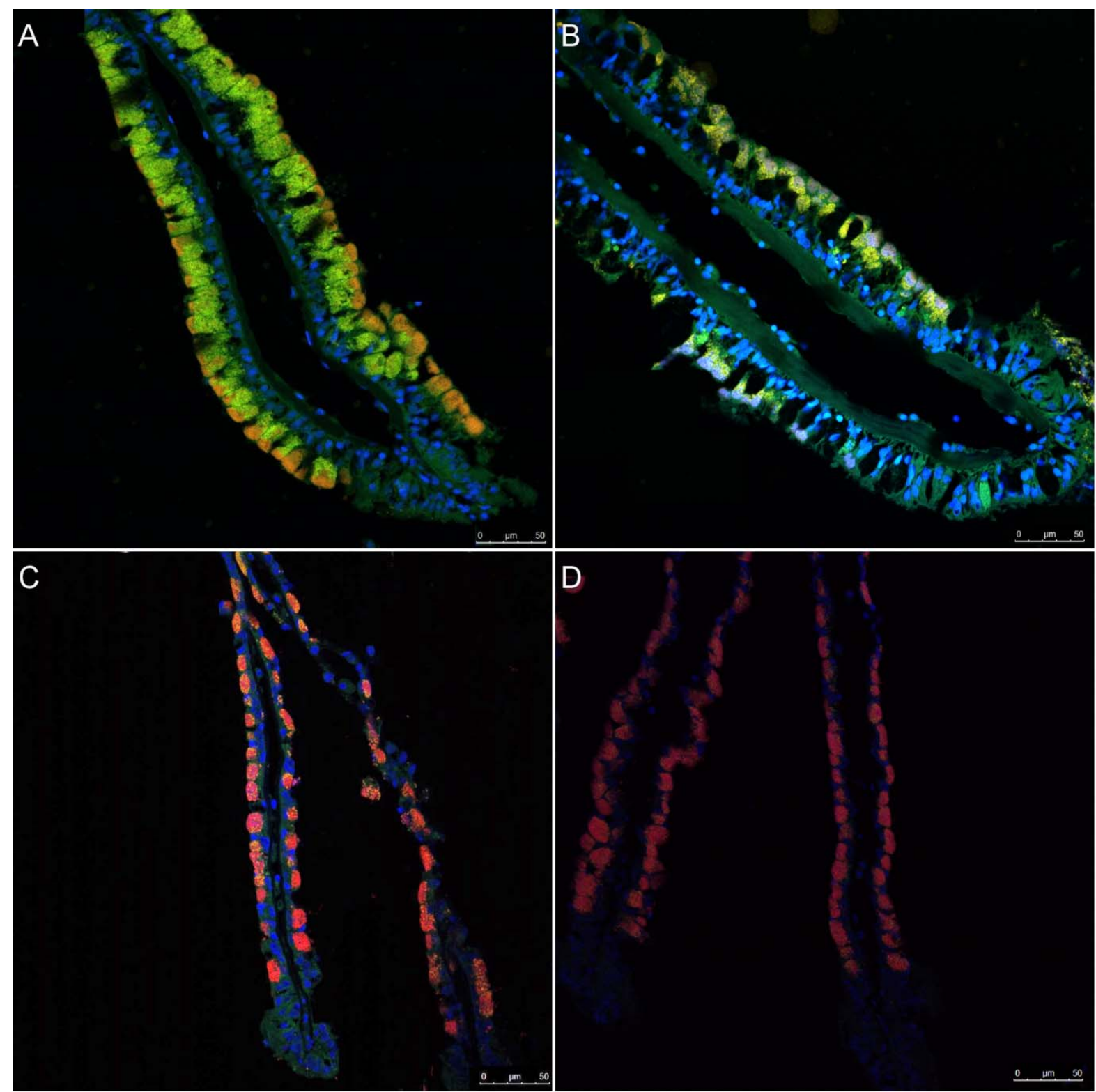

Fig. 3 Localization of MOX (green, FISH probeImedM-138) and SOX (orange, FISH probeBangT193) symbionts in gill cross-sections from B. aff. boomerang with high (A), and low (B) MOX symbiont content and from B. azoricus with high (C) and low (D) SOX symbiont content. Host cell nuclei are blue (DAPI). 